\title{
The Comparison of the Forms of Land Capability Classification of Atalay and USA in Eskişehir Province (Turkey)*
}

\author{
Mücahit Coşkun\#, Ayşe Nur Uzun Turan \\ Geography Department, Karabük University, Karabük, Turkey \\ Email: "mcoskun@karabuk.edu.tr
}

How to cite this paper: Coşkun, M. and Turan, A.N.U. (2016) The Comparison of the Forms of Land Capability Classification of Atalay and USA in Eskişehir Province (Turkey). Journal of Geoscience and Environment Protection, 4, 72-92.

http://dx.doi.org/10.4236/gep.2016.413005

Received: November 25, 2016

Accepted: December 26, 2016

Published: December 29, 2016

Copyright $\odot 2016$ by authors and Scientific Research Publishing Inc. This work is licensed under the Creative Commons Attribution International License (CC BY 4.0).

http://creativecommons.org/licenses/by/4.0/

\section{(c) (i) Open Access}

\section{Abstract}

Turkey is an area where climate changes immediately, vegetation, or land gets different in a short distance. Geological and lithological features show diversity. Also, our country's territorial existence and diversity also bring about different land use conditions. Therefore, land capability also differs from each other. Nevertheless, the classification of land capability used in Turkey is the classification of land capability for agricultural lands prepared by the United States (USA) in 1961. Due to this, [1] have made suggestion on a new classification of land capability considering our country's geographical conditions. In this study, comparing the land capability with the classification carrying out in our country, the classification which Atalay and Gündüzoğlu suggested, has been aimed. Working method has been established according to regional approach and field observations have been done. In preparing the cartographical material, ArcGIS 10.3 has been used. The map of this study as a material topography, physical map, slope, aspect, the usage of the land, ground, geology, land capability, geomorphology, temperature, and precipitation has been examined, meteorological data have been appreciated. According to the findings attained, Eskişehir's map of land capability has been done through the criteria of the suggestions of Atalay and Gündüzoğlu. As a result, it has been understood that there is a difference between the USA land capability that applied in Eskişehir and Atalay and Gündüzoğlu's criteria. In the study, it is suggested to determine the land capabilities again considering the ecological conditions of Turkey.

\section{Keywords}

The USA Land Capability, Atalay Land Capability Classification, Landuse, Geography, Eskişehir, Turkey

${ }^{\star}$ Part of the study was shared in GEOMED 2016. 


\section{Introduction}

Soil which provides the subsisting of the human existence has been played a part in everyone's heart, life of the philosophers' or a stringed instrument of a poetsinger's. Soil has sometimes become Aşı Veysel's "faithful lover"; sometimes one of the most precious four elements of Empedokles...Empedokles compresses the lifecycle into four elements and puts the most precious one, land, to the top. He tells the human beings; "Do not forget! One of the corruptions infects the others". Human being has brought much environmental pollution along by the activities they had done owing to not complying with this call. Despite all the degradation and misuse having been done by human beings, soil continues to renew itself and give products instead of showing ingratitude. The cases such as unconscious use of the environment, erosion, deforestation, urbanization, improper land use, industrialization have been destroying soil or soil productivity. In these cases, the growing population in the world, the destruction and the oppression of the human activities on the natural environment have important roles. When increased demand and dwindling resources are considered, it has been a necessity for humans; they require ensuring the highest yield from the land.

According to the data of FAO [2], the world's population's dependence on land for food, fuel and employment is expected to be doubled in the next 50 years. In today's technological conditions, as the soil cannot be enhanced and the yield of the using lands will be reduced over the years, certainly; it should not be used over its purpose [3]. Therefore, for sustainable development, it is necessary for the countries to make a land planning. For this purpose, almost all countries are making serious efforts for land assets and planning. Thus, in almost every country in the world after 1950s, the policies to benefit from the land have implemented. Land has been brought into human use by classifying according to its features [4]. In order to achieve this aim, the land classification in every country should be done according to their own properties and this is essential.

While doing land classification in Turkey, the methods and the materials implemented by "US Department of Agriculture Soil Conservation Service" are taken into consideration. The US Classification System which is mostly related to agricultural land appears to fail to comply with the properties of our country. Because the topography of our country is high and our country is sloping, about two-thirds of the land includes the lands which should be used as pasture and forest those are unsuitable for farming. In addition, land in our country, since it is used continuously for thousands of years, the destruction especially in sloping field, has reached its last stage and lost its productivity partly. Apart from these, ecological conditions in different regions of our country necessitate the creation of different land capability classification [1] [5].

Babalık [6], Buldan and Gülersoy [7], Ünaldı and others [4], Gülersoy [8], 
Gülersoy and Çelik [9], Gülersoy and others [10] have revealed the discrepancy between land capability classes and land uses in their work. In the Tenth Development Plan, The Republic of Turkey, The Ministry of Development has addressed the problems of land use "2014-2018" as a result of using the land capability classification for different purposes. Studies so far have tried to explain the deficiency and mistakes in the land capability classification system which is still in use. However, Atalay and Değerliyurt [5] have introduced a new concept in the land capability classification at Burdur Basin. While making this classification, the authors have benefited from the classification which has been proposed by Atalay and Gündüzoğlu. A large part of the work that has been done on the subject is about the inaccuracies arising from land use or land use issues. In the researches carried out currently on Turkey land capability, the necessity of the new classifications has been focused on.

The aim of this work is to make a comparison between the land capability classification which was prepared and implemented according to the US system in 1978 and the classification proposed by Atalay and Gündüzoğlu. For this purpose, as a sample, the land capability applied in Eskişehir has been taken into consideration and it has been worked up to the results by comparing the two different classification systems. It has made the research important that this kind of work's being done for the first time in the scale of Eskişehir in Turkey. In terms of the dissemination of such research and opening the form of Turkey land capability classification up for discussion, this research will be one of the important examples.

\section{Field of Study}

Eskişehir is located in northwestern part of Central Anatolia Region between $29^{\circ} 59^{\prime}-32^{\circ} 04^{\prime}$ east longitudes and $39^{\circ} 06^{\prime}-40^{\circ} 09^{\prime}$ north latitudes. It is adjacent to city of Bolu in North, city of Ankara in northeast and east, city of Konya in southeast, city of Afyon in south, cities of Kütahya and Bilecik in West (Map 1). Eskişehir consists of 13 towns in total. These are Odunpazarı, Tepebaşı, Alpu, Beylikova, Çifteler, Han, İnönü, Mihalgazi, Mihalıççı, Mahmudiye, Seyitgazi, Sarıcakaya and Sivrihisar. According to General Directorate of Rural Services Publications, the city's surface area is 1365.248 hectare [11].

Eskişehir is one of the agricultural plains located in the Central Anatolian part of Turkey. The current plains are $26 \%$ of the province's surface area. Considering the fact that the plains of our country are limited, the Eskişehir plain is very important. In addition, there are covered farming practices that we are not used to seeing in the inner regions. Due to these applications, more than one product can be purchased per year. For this reason, the land capability classification system in Eskisehir province has been examined and the US terrain capability classification system and Atalay and Gündüzoğlu's land capability classification system have been compared. 


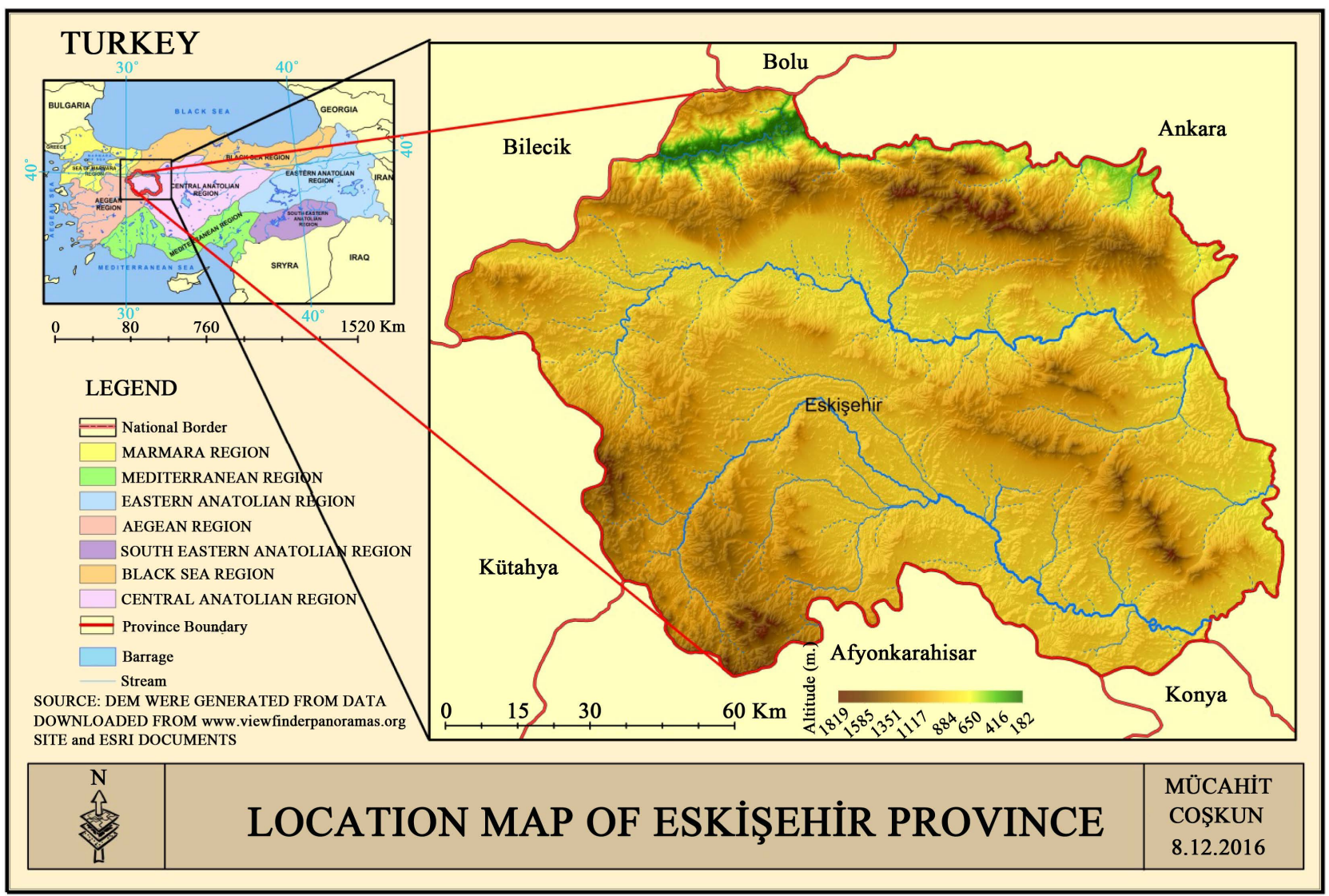

Map 1. Location map of Eskişehir Province.

\section{Material and Method}

The study has been carried out in 3 stages. The first stage is a desk study and includes writing a literature review, obtaining statistical data, supplying the land use maps and preparing other cartographical materials. Packaged software of ArcGIS 10.3 has been made use of preparing the cartographical materials.

The second stage includes field survey. The area was visited in 2015 and 2016 for this aim. Field observations were marked on the land use map and existing problems were observed on the spot. The land use and the place of it in the classification of cross-country were examined. It was also compared with the new system of classification which belongs to Atalay and Gündüzoğlu.

The third stage is again a desk study. All the information obtained from field study and the existing literature and maps were evaluated in this final stage. According to the system of Atalay and Gündüzoğlu [1], Eskişehir's new map of land capability classification was drawn.

Principles of both systematic and regional approaches were used in the research method. The basic of "from part to whole" was considered in the regional approach. As for holistic view, it was cared to be appropriate for the perspective of systematic approach. 


\section{Findings and Discussion}

The systems for classification of the field have been formed by developed countries in order to make the best of existing natural sources against increasing population with Industrial Revolution. For instance; local planning made by America of 1930s, the studies of "Land Use Survey" made by England in 1922, the report of "SCOTT" published in 1941 explained the use of natural environment and how it should be used [12]. The system of land capability classification determined by USA Soil Conservation Service in 1976 gave priority to topsoil. Moreover, possible erosion situation of soil was dealt according to resettlement and damage of land existed in agrarian zone. For this aim, soil has been classificated as two team four each. Some lands are suitable for forest and grass growing, however, class I lands and class IV lands are privileged for agriculture. Class V-VII lands are lands that are not used for agriculture but mostly used as pasture and forest. Land that belongs class VIII is non-agricultural land [1]. The aim of land capability classification is to supply the highest rate of vegetation production by protecting the natural potential. In order to reach this aim, land classification is made by considering topography (slope, exposure, elevation), basic material and features of soil. Land is classified in order to determine the cultivated area, grazing land and forest land and to get the highest efficiency by protecting the land. Land capability classification has been done by Earthy Organization in our country according to the criterions used in USA. It was published in 1978 under the name of Turkish Land Size. Lands are marked as 8 different classes in this classification. While class I, II, III and IV lands are the fields that are cultivated areas; the class V, VI and VII lands are grass and forest lands that are non-agricultural lands. Class VIII lands such as marsh, stony area, wetland are the areas that are not useful but suitable for supplying water and being shelter for the wild animals and supplying food for them [1] [5] [12].

Features of new system land classification made by Atalay and Gündüzoğlu [1] which is one of the classifications within the scope of research are given below:

\section{Cultivated Areas According To Atalay and Gündüzoğlu Class I Lands}

- Climatic conditions will not have a restrictive effect on agriculture.

- There will be lands that are plain or almost-plain with a good drainage.

- Soil will be thick enough, fertile and including mostly alluvial and terra rossa.

- Because of the fact that vegetation period continues during almost one year, getting crops at least two times from watered areas are lands that belong to class I.

- Class I lands are important cultivated areas generally used for growing industrial crops such as cotton, corn, sunflower and different kinds of vegetables and citrus fruits. 


\section{Class II Lands}

- On the areas that there is not much restrictive effect of climatic conditions,

- On the areas that have gentle slope with no risk of erosion,

- On the areas that rarely have risk of overflow, the problem of moisture handled with the help of drainage,

- On the deltas whose soil is reasonably thick and near the areas that belong to class I or the areas that have outcrop materials with marn, clayed,

- On class II lands, usually some industrial crops such as sugar beet, corn, sunflower and different kinds of crops, especially fruit, vegetable and grain, are grown.

\section{Class III Lands}

Include the areas that:

- are reasonably sloping that causes erosion,

- have the soil stony-even if it wouldn't be much-, reasonably thick or smooth sedimentary that can be cultivated,

- have sometimes overflows at river banks,

- cause decrease in efficiency in crops because of drought and frost that occur in some years,

- These are the areas that are used for growing some fruits and vegetables thanks to watering, however, have some soil problems such as being stony and having the risk of erosion, a restrictive effect of climate such as drought and frost in the terrestrious region of Anatolia.

\section{Class IV Lands}

These are the areas that:

- Are sloping and have a shallow soil because of erosion,

- Have less moustire holding capacity on plain places,

- Have partly increasing in depression bases in terms of wetness because of being undrained temporarily and high groundwater,

- Climate, especially drought, causes decrease in efficiency of crops,

- Until recently, lack of soil forming in our country's subarid regions is due to lacustrine environment and continuous precipitation of sand, mil and thin ingredient material that is in the size of clay in this environment. These areas become suitable for growing fruit trees, some of the forage plants and even vegetables with the help of watering and porch system that is set to prevent erosion. Grain, grape and mulberry are grown with caution of protecting soil.

\section{Non-cultivated Areas According To Atalay and Gündüzoğlu Class V Lands}

- Bottom lands covered with gravels and sand that come as a result of continuos overflows.

- Plain places with a high quantity of groundwater that prevents growing of crops.

- Alluvial cone and alluvial fan that form low-pitched field that spreading flows coming from gulleys of mountain foot. 
- These areas are fields with sandy soil that decrease in water-holding capacity.

- Because of those features, class V Lands cover less space in our country. Class VI Lands

- Climate's being suitable for growing of herbaceous vegetation,

- Soil's being too shallow and stony to cultivate,

- Area's being available for growing herbaceous vegetation to some extent in spite of soil problems such as being brackish and alkalinity,

- In spite of being under the farming regime and forest regime, existing of plain spaces that are suitable for growing herbaceous vegetations also,

- These areas take part in our country from seaside to alpines and half-alpines that are above forest boundary.

- According to circumstances of Turkey, class VI lands suitable places for being used as meadow. However, some lands that belong to class VI whose climates are proper can be turned into suitable places for growing some kind of crops with the help of intense reclamation cautions.

\section{Class VII Lands}

These are fields:

- That erosion can be seen because of the fact that they have high pitch, so the main material surfaces from place to place.

- That have no proper soil and main material to do agriculture.

- That are usually mountainside whose climate is suitable for forest vegetation.

- These areas are under the forest cover.

- VII class lands that take part on mountainside are the areas that take up the most space in our country.

\section{Class VIII Lands}

- Are places that have no proper soil and land structure for growing crops with a commercial aim.

- Are rocky and stony areas that exist in high mountainside.

- Are areas with saline and alkaline that prevent growing of vegetation cover.

- Are marsh that hosts the wild in a broad sense: wetlands.

- Are waterfront running sand dune.

\section{Example Land Capability Classification of Eskişehir}

Eskişehir is a city that varies in terms of geographical formations, basic material, climate and features of soil and vegetation cover. Effects of these factors in land classification and their general features are indicated below:

\section{1) Geographical Formations}

Eskişehir is located in northwest edge of Central Anatolia. Topographic structure of the city consists of two large plains that exist in drainage basin that belongs to River Sakarya and Porsuk-its tributary-and mountains that surround all of those. Plains that are surrounded just like a rampart have idiocratical agricultural activities. Elevations that surround the city of Eskişehir are moun- 
tains of Bozdağ and Sündiken in North, Türkmendağ 1 in West-southwest, plateou of Yazllikaya, Emirdağ's extensions that extend along the city, mountains of Sivrihisar that extend along from the city's southeast to its northwest. The highest point of Bozdağ is the hill of Türkmenbaba and it is 1534 metres. The highest hill of Mountain Sündiken is Kızlldağ that is 1818 metres. Mountains of Sivrihisar have a threshold-like look and the highest point of them is 1690 metres. (Map 2).

It is the lands from first geologic time that are encountered geologically mostly in provincial border of Eskişehir. The mass of Bozdağ-Sündiken that is in North of the city and mountains of Sivrihisar that have their way from northwest to southeast exist on the West border of the city. These are intracity extensions of the mountains that belong to threshold of Western Anatolia. Most of the mentioned mountains are first geologic time fields. Moreover, second and third geologic time fields exist quite much in the surface of that mountainside mass as well as the first geologic time fields. Neogen formation of lake that belongs to 3 .

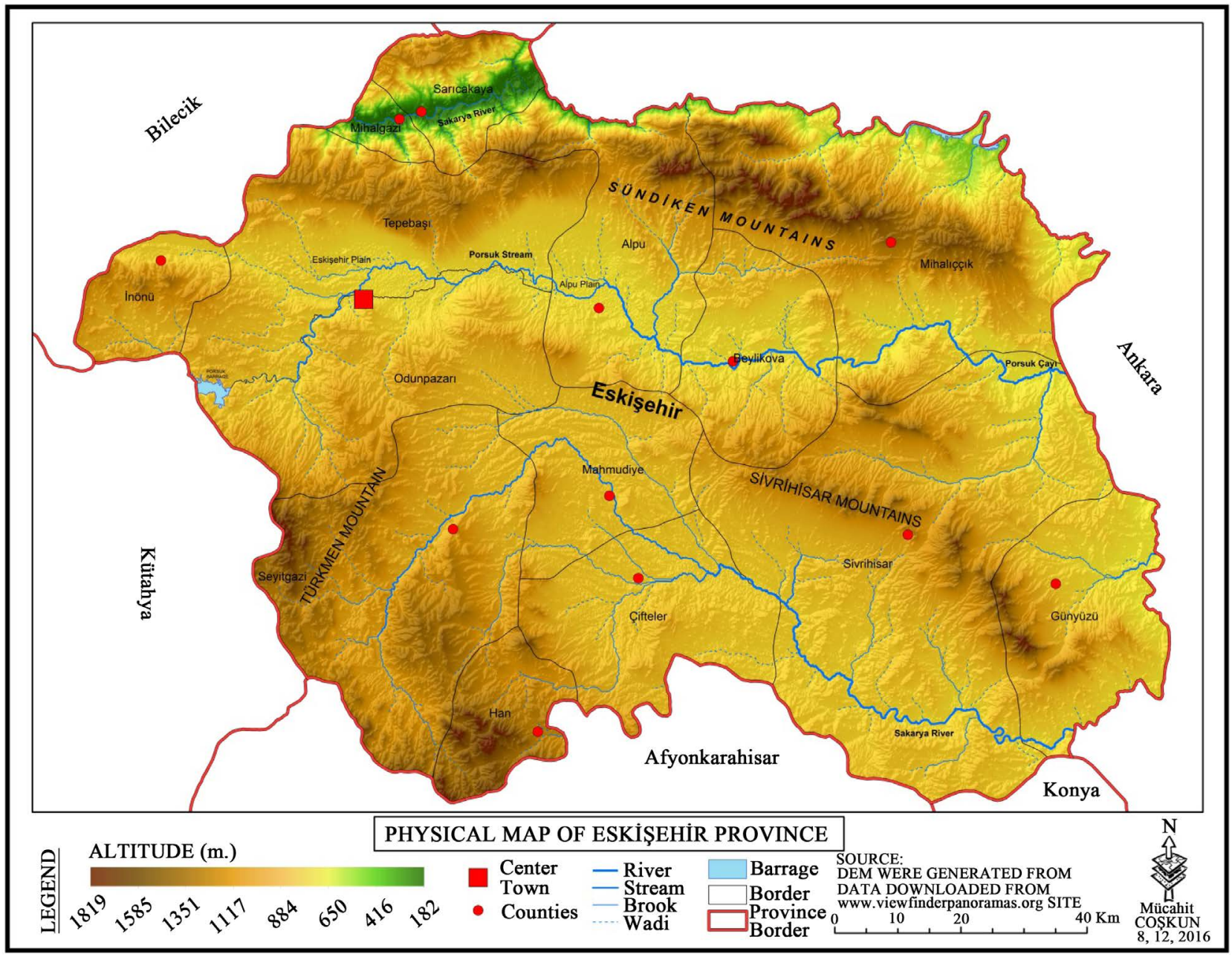

Map 2. Physical map of Eskişehir Province. 
Geologic time and fluvial ripraps that belong to 4. Geologic time exist in Porsuk and Upper Sakarya Area.

\section{2) Basic Material}

Ofiyolit-metamorfik-metadetritik material that is formed before Jura exists at the bottom of Eskişehir. Jurassic lands are generally formed by detritic material and limestones. Paleocene, Eocene, Miocene and Pliocene sediment and volcanic rocks exist on the marbles that belong to the period pre Jurassic age and Jurassic age. The youngest unit that is pleistocene includes sand with natural cement whose lithologic structure is slack, gravel and claystone. There are granites with porphyritic texture as plutonic rocks; andesites, tuffs and basalts as volcanic rocks in the city [13]. According to the explanations of Atalay and Mortan [14], marbles and shields commonly exist in the mountains of Sündiken that is in North of the city. Clayish and cretaceous sediments accumulate in Eskişehir's plain at the lacustrine environment that is formed in Pliocene period. Moreover, there are granites in Sivrihisar that is in southeast of the city.

\section{3) Features of Climate}

Climate classification has been done according to Erinç and Thorntwaite by taking advantage of data that belong to 1950-2015 taken from general directorate of state meteorology [15]. According to rainfall effectiveness of Erinç, Eskişehir has a semi-arid climate. According to Thorntwaite, centre of Eskişehir is semiarid area that is one of the mesothermal climates. Whereas the districts of Eskişehir (except Günyüzü) are semi-moist when evaluated according to Erinç's annual precipitation occasion.

Apart from the fact that Valley Sakarya that has a mild winter because of the fact that it exists in a sheltered valley; harsh continental climate rules over Eskişehir [11]. According to data taken from meteorology, average annual temperature of Eskişehir is $11.01^{\circ} \mathrm{C}$. While July and August are the hottest months, January and February are the coldest months in the city. Average annual rainfall is $370 \mathrm{~mm}$ [15]. Rainfall decreases in south and northwest of the city. Rainfall rate becomes the highest rate in February-March, May and December. Rainfall decreases in July-August-September. Frost begins with the first week of September and continues till mid of May. Frosty weather begins with first week of October and continues till first week of May [11].

\section{4) Use of Soil and Land}

Large soil types are formed in Eskişehir because of the climate, topography and basic material diversity. It is observed that brown soil has the largest distribution on Eskişehir soil map (Map 3). There are 610.889 hectare of brown soil in Eskişehir according to Rural Services General Directorate Publications [11]. Brown soil which is generally seen in the areas in which the leaching is limited and the average annual rainfall is around $250-400 \mathrm{~mm}$ spreads over the Centrum, Günyüzü, Sivrihisar and the North-Eastern part of Seyitgazi. The brown forest soil which is formed mostly under the broad-leaved forest cover is widely seen in Mihalıççı, Seyitgazi, Sarıcakaya regions and the Southern and South- 


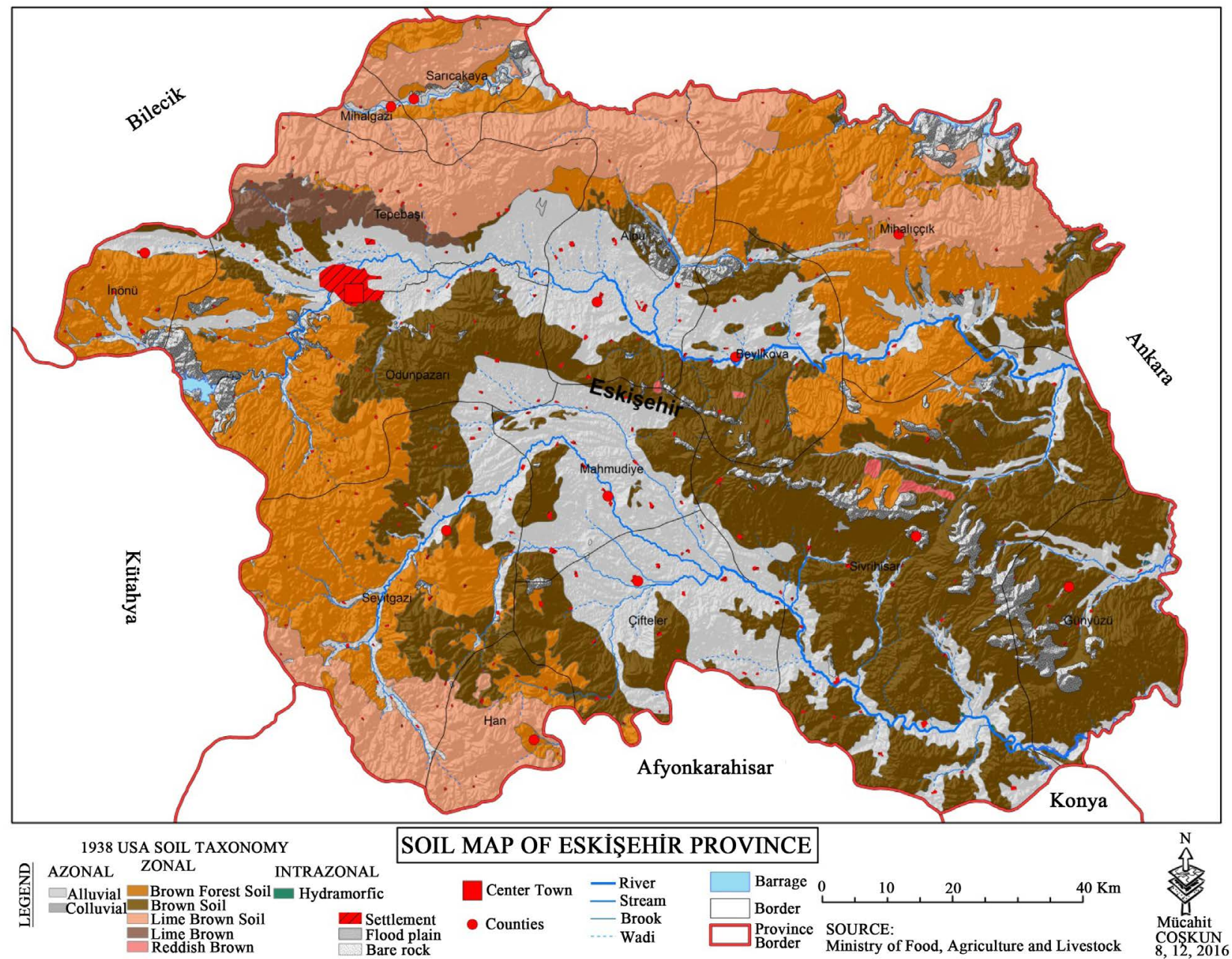

Map 3. Soil map of Eskişehir Province.

western parts of the Centrum. Lime-free brown forest soil which is also formed under the broad-leaved forest cover mostly lies between Alpu and Tepebaşı, Mihalgazi, Sarıcakaya which are also the central towns of the city. Besides, this type of soil can also be seen in Mihalıççı and Han. Alluvial soil is seen in Porsuk and Upper Sakarya Plains and in the other river valley plains of the city. Alluvial soil is fertile soil which is sufficient to grow any kind of cultivated plants and which can acclimatize easily. Lime-free brown soil has rather small distribution in the city. Besides there is colluvial soil on the sloping hillsides of the city and in embouchure. There are also decomposed or partly decomposed rocky areas which are deprived of soil cover. But this type of land has rather small part on the city's overall surface area.

Brown soil which has a big part in the soil distribution of the city according to data taken from Rural Services General Directorate [11] are mostly used as pasture. Mostly dry farming and something of irrigated farming takes place on the lands of Eskişehir's plain part. However, irrigated farming takes place on most 
part of alluvial soil which are located in riversides. High lands which are located in Northern and South-Western parts of the city are utilized as forest and heathland (Map 4).

\section{5) Land Capability Classification of Eskişehir}

It is much more relevant to topsoil, currently used classification system whose land capability classification changes from I to VIII and that is originated from USA in order to have the most efficiency of our country's lands.

Gülersoy [12] has defined class I lans as "deep and fertile lands that can be easily cultivated, well-drained soil that you can grow any kind of crops on". While land use map of Eskişehir is examined, it is seen that class I lands of the city are in the places that Porsuk and River Sakarya and branches that belong to these streams exist (Map 5). 56.6\% of class I lands is brown soil. $77.2 \%$ of class I lands whose slopes are lower than $2 \%$ has deep land, rest of it has mid-deep land. Irrigated farming is mostly done on the class I lands of the city [11]. Yiğitbaşığlu [16] has explained in his research that while class I lands of Eskişehir used for agriculture in 1958, they have been opened to settlement from 1994 until now.

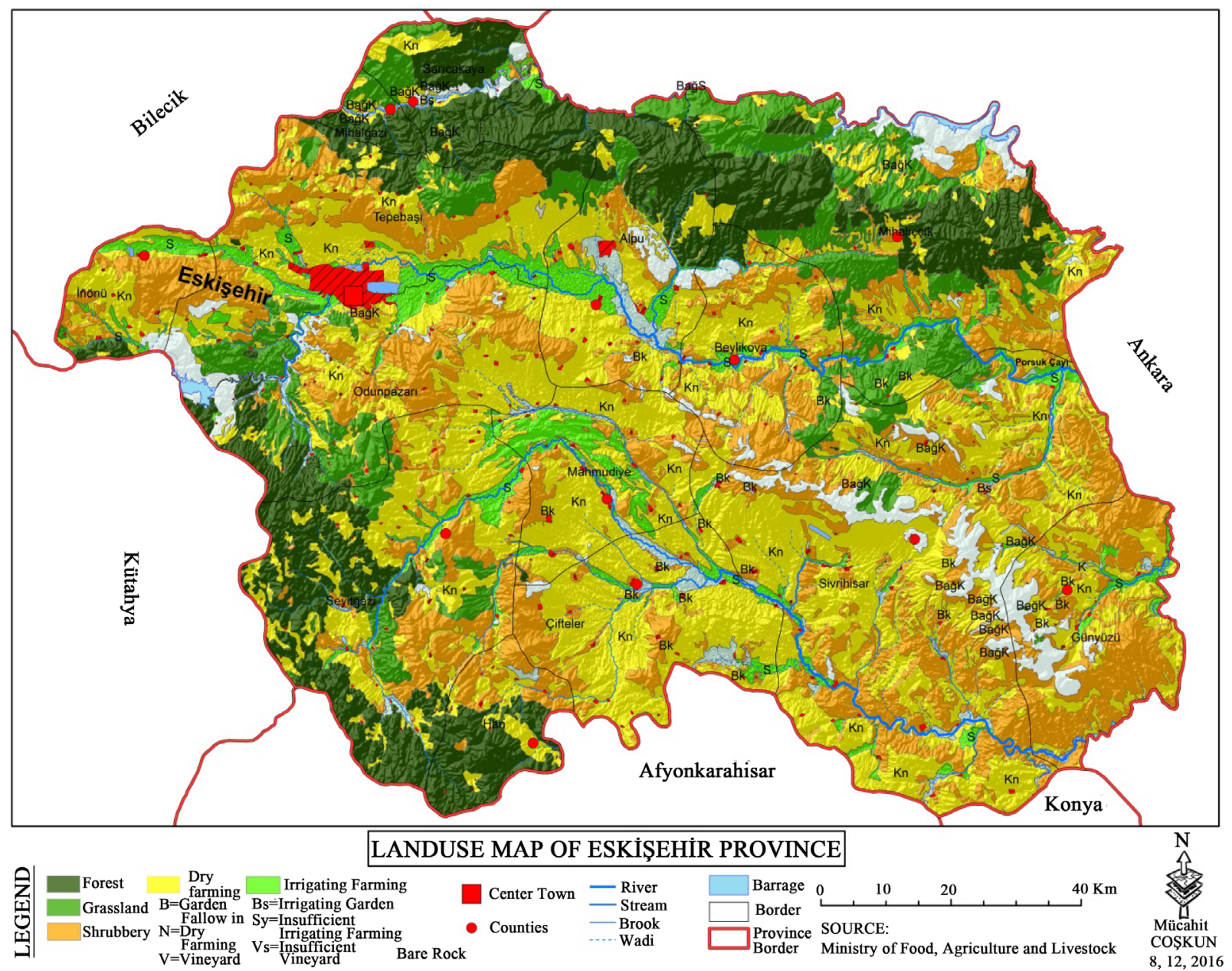

Map 4. Landuse map of Eskişehir Province. 


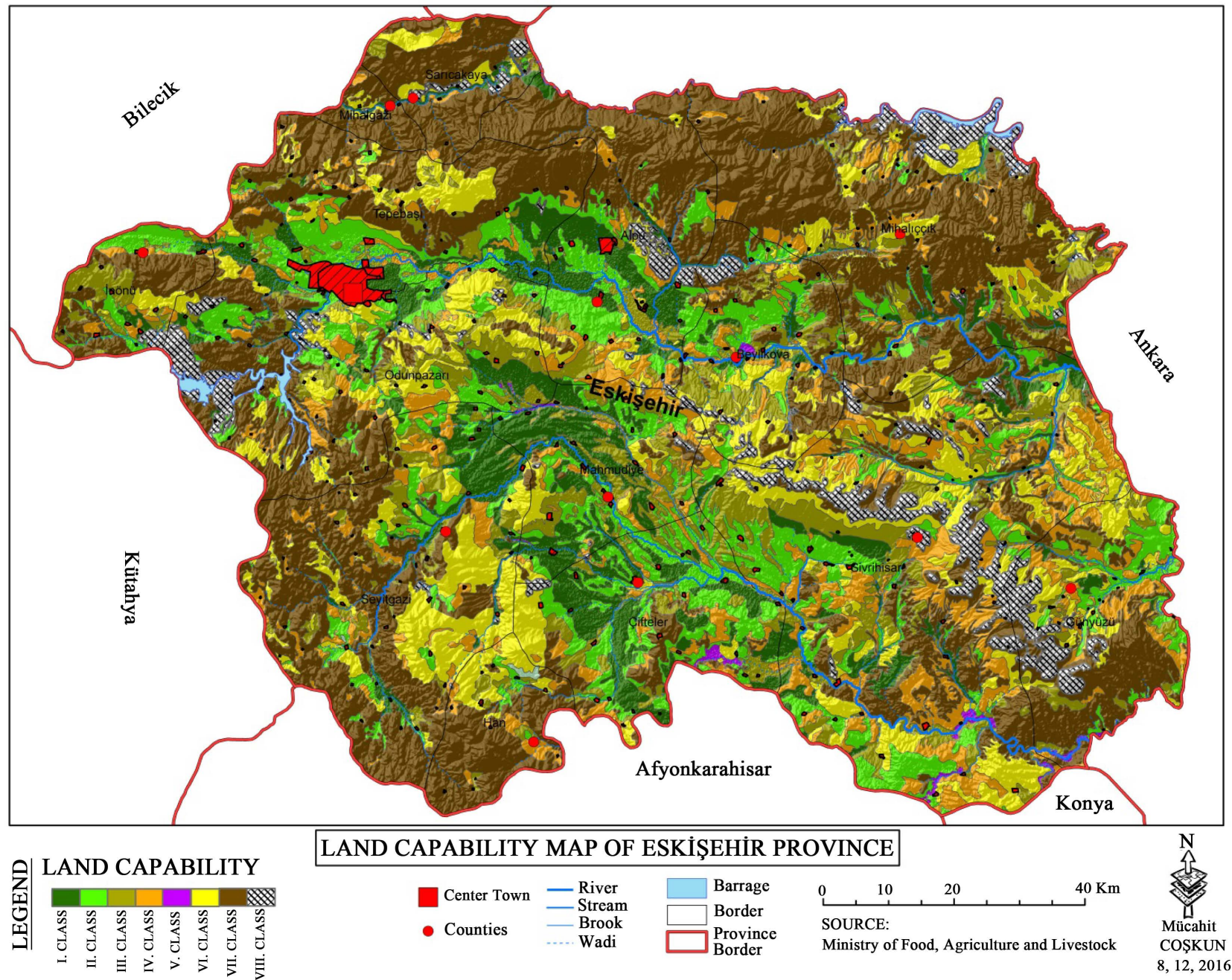

Map 5. Land capability map of Eskişehir Province.

Class II lands are lands that are less suitable for growing any kind of plants. Soil and hydrographic features require special cautions [17]. While land use capability map of Eskişehir is examined, it is seen that class II lands are usually near class I lands (Map 5). 69.7\% of class II lands is brown soil. Slopes of $16.6 \%$ of these fields are between 0 - 2 and slopes of $83.6 \%$ of there fields are between $2 \%-6.46 \%$ of soil is deep and $54.1 \%$ of soil is mid-deep. Erosion with mild and mid degree rules over most of the field. There is $\% 14.9$ wetness in this class. Dry farming is mostly done on class II lands of the city [11].

According to Ministry Of Agriculture and Rural Services, General Directorate Of Agricultural Production and Development 2008 Soil and Land Classification Standard Technical Directive and relevant legislation [18], class III lands are fields with problems such as having mid-slope, being too sensitive about erosion, having too wetness, being stony and fields that require special cautions in order to increase efficiency of crop. $30 \%$ of the city's surface consists of class III lands. $66.5 \%$ of class III lands is brown soil. $62.2 \%$ of this class is mid-slope soil. Mid- 
degree erosion rules over $82.5 \%$ of class III lands. Dry farming is mostly done on this field [11]. Yiğitbaşığlu [16] has emphasized in his research that class II and class III lands of Eskişehir increased in 1958-1994, however, these areas that are suitable for agriculture mostly used as settlement places and industrial installations.

Class IV lands have some harsh restrictions such as depth of soil, being stony and slope. However, they are fields that become suitable for agriculture when it is applied very serious methods for protecting soil such as terracing, in a little while drainage [12]. $10.4 \%$ of the city's surface consists of class IV lands in Eskişehir. $87.5 \%$ of this class is soil with mid-slope. $89.5 \%$ of class VI land has shallow soil and $73.3 \%$ of this land has high degree erosion. These lands are usually used as land of dry farming and grass-pasture field [11].

Class V lands are flat or nearly flat and rocky fields which can not be ploughed. Underground water is close to surface. These areas can be utilized as meadow or greenwood. Eskişehir Office of the Chamber of Agricultural Engineers [17] Gülersoy [12] described the class V lands mostly as rocky lands (accumulation cone), sandy and stony fields which are flooded time to time. Class V lands compose $2.3 \%$ of Eskişehir's overall surface area according to General Directorate of Rural Services Publications [11]. All of this area consists of brackish, salty, flat and deep hydromorphic alluvials and is mostly used as grass-pasture fields.

Class VI lands are the ones which need medium level caution even if they are utilized as forest or meadow according to 2008 Soil and Land Classification Standard Technical Directive and relevant legislation of General Directorate of Agricultural Production and Development, Ministry of Agriculture and Rural Services. The land is sloping and there is soil errosion. Class VI lands compose $12.5 \%$ of city's overall surface area. Most of class VI lands consist of brown forest soil. $53.3 \%$ of these lands are steep, $80 \%$ of them are very shallow and vast majority of them are utilized as pasture [11].

Class VII lands are shallow fields that include stony soil in the areas with slope and high degree erosion is seen on. They are not economic for agriculture but are used for planting poor pasture and forest trees [17]. According to General Directorate of Rural Services Publications [11], 37.2\% of city's overall surface consists of class VII lands in Eskişehir. 95\% of fields that are belong to this class are soils of the areas with high degree slope and erosion is very harsh on these areas. Most of the lands that belong to this class are used as pastures.

Class VIII lands are not suitable for using as cultivated area, forest or pasture just like the rocky areas, marsh lands and areas with too salt. These areas are mostly used for tourism, entertainment and resting and used as shelters for game animals [12]. 4.3\% of Eskişehir's overall surface consists of VIII class lands. Class VIII lands are mapped as floodplain of river and bare rock [11]. 


\section{Conclusions}

The land capability system which implemented in Turkey is a land capability classification system used by the United States. This classification system as prepared according to United States is especially concerned with agricultural land. Nearly two-thirds of the land in Turkey is not suitable for agriculture used as pasture and forest land. Furthermore, land capability classification system used in Turkey is not suited to the conditions in Turkey because of the Turkey's having an extremely rugged topography, prevalence of different climatic conditions, have the characteristic structure of largest section of the main materials and the world soils, have a variety of geomorphological units, existence of the bed rock especially in areas of devoid from ground cover [1] [5]. For these reasons, Atalay and Gündüzoğlu have proposed a new land capability classification system in accordance with the conditions of our country. New land capability classification system's created by Atalay and Gündüzoğlu compared with the currently used classification system, it has reached the following conclusions:

According to Turkey's land capability classification which created by Atalay and Gündüzoğlu:

- There is no class I and II. Class land around Eskişehir and surrounding land. Therefore, land of accepted as class I and II. Class lands are more accepted as class III and class IV places (Map 6).

- According to Atalay and Gündüzoğlu, "climatic conditions should not being restrictive effects on agriculture" and "vegetation period to going on throughout the year and thus taking to fertilize at least twice in year these areas" are conditions of being first class land. Therefore, according to Atalay and Gündüzoğlu, extremely rarely area in our country have these conditions as more in the Mediterranean climate areas.

- Land area of used for irrigated agriculture in the accepted as class I and class II lands according to USA classification system in Eskişehir land is a class III lands in reality. Atalay and Gündüzoğlu have identified class III areas as "some fruits and vegetables are grown on irrigated land in semi arid-semi humid areas in hinterland".

- Under dry farming areas in class I and class II land in the Eskişehir and surrounding land is IV. Class land. Authors have identified class IV areas as "grown cereals in dry land agriculture in land areas of semi-arid areas".

- There is no class IV land around Eskişehir according to Atalay and Gündüzoğlu. Because such lands are with drainage problems for "often results in flooding covered with sand and gravel".

- Considered as class V, places in the currently used Land Use Map are more regarded as class VI lands. Authors, characterized features of class VI land as "Our semi-arid region, at plateau, in the shallow and stony soils, in areas where brown chestnut color, and more appropriate place for use as pasture". 


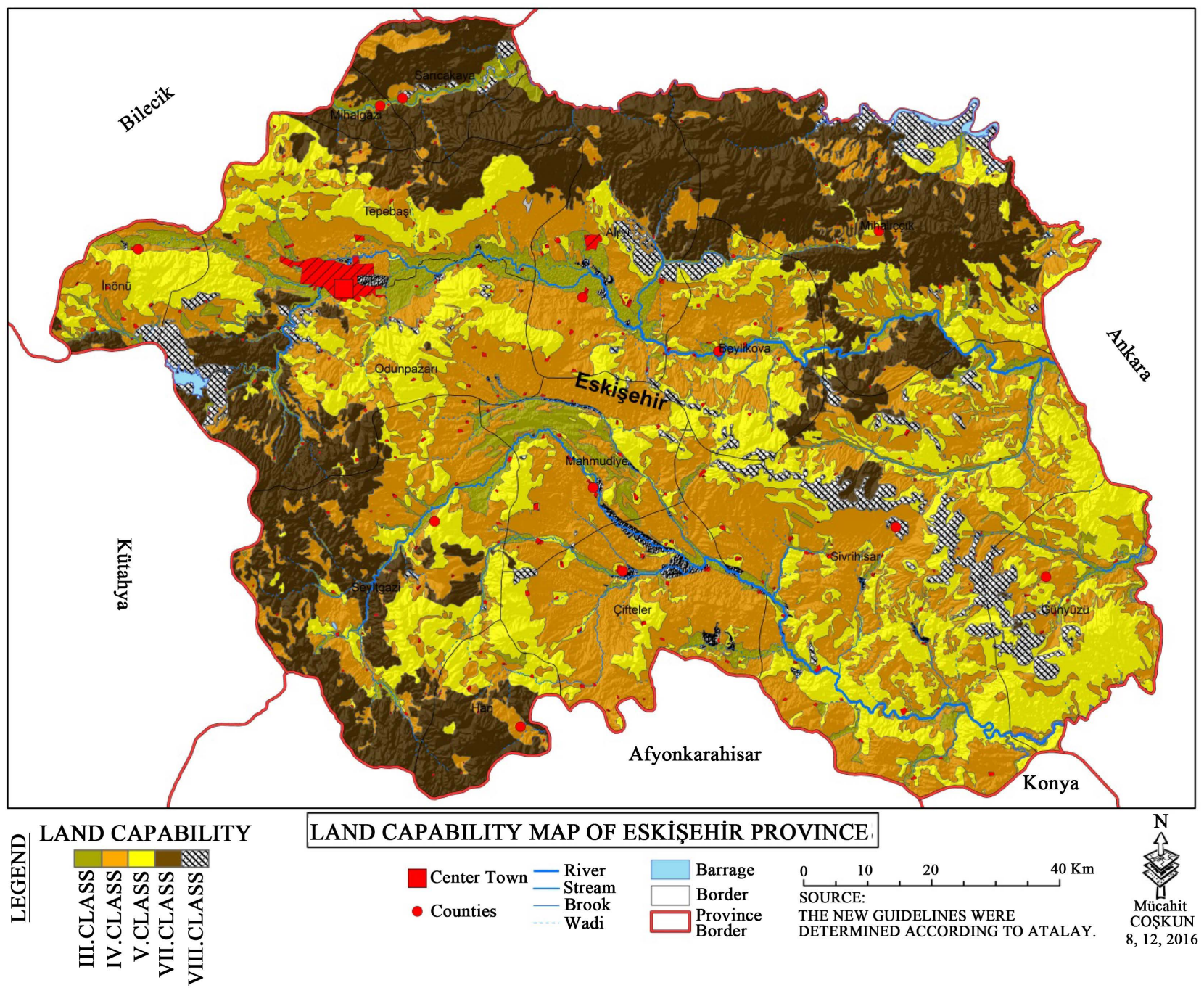

Map 6. Land capability map of Eskisehir Province by Atalay and Gündüzoğlu.

- According to Atalay and Gündüzoğlu; used as pasture-grasslands are considered as the class VI land.

- Because as Atalay and Gündüzoğlu specified class VII in our country as "places should remain under permanent forest regime" located in areas under forest cover in Eskisehir defined as class VII (Map 6).

- Because finding about VIII class land by Atalay and Gündüzoğlu are the same VIII class terrain of the General Directorate of Rural Services, this type of land classification didn't change.

Atalay and Gündüzoğlu have created a new land capability classification to increase the yield of the soil to be suitable for our country. Purportedly, this classification is more realistic and workable classification than those applied by the United States. However classification system of Atalay and Gündüzoğlu is too new and for some points, this classification system will be open to discussion. When analyzed the new land capability map that suggested by Atalay and 
Gündüzoğlu, it has been found to be incompatible with field observations of places in Eskişehir on this map. The reason for this is that the scale of the map of laudability map prepared for Turkey is small; the detail is low and general. The reasons such as the specific location features of the local places to the foreground, the increase of the details, the use of a large scale map according to the Turkish map reveals the differences. In this case, the best practice is to adapt the general principles outlined in the class to local features. Our most important standard in highlighting local features is making observations at the scene, and matching the data about the field with the scenes has been the main motivation for the authors of this article. In addition, in the interview with Atalay [19], he was told about the subject. Atalay remarked related to the topic; and that there may be local differences in Turkey's scale and that these differences can be rectified by increasing the number of local studies and conducting on-site observations and researches.

A new map created in the whole province eliminated incompatibilities with related research and field observations on land capability classification map made by Atalay and Gündüzoğlu (Map 7). Issues mismatched on land capability classification map with real land given in the following headings.

- Agricultural lands of Sarıcakaya and Mihalgaziwhich on the edge of Sakarya River and located in north-west province is classified as class I land.

Sarıcakaya and Mihalgazi towns are located in a sheltered valley on the edge of Sakarya River. These two countries have a more moderate climate than the Central Anatolia climate because they have sheltered places in it and according to Emberger semi-arid Mediterranean climate has been observed. Therefore irrigated agriculture and greenhouse operations held in the Sarıcakaya and Mihalgazi can be provided products 4 - 5 times a year. So climatic conditions in these two counties do not present a limiting effect on agriculture. Alluvial type of soils of the Sarıcakaya and Mihalgazi, in term of rainage, slope, soil thickness and efficiency described by Atalay and Gündüzoğlu, woke terrain Class I land. Therefore, these two districts may be Class I land.

- The lands, alluvial soils on the river side of Sakarya, Porsuk and other rivers in Eskişehir Plain and on the edge of Class I lands defined by Atalay and Gündüzoğlu is class II land (Map 7).

Industrial plants such as sunflower and sugar beet, cultivation is done in the watered area on the edge of river in Eskişehir Plain. According to interviews with encountered farmers during field trips and Eskişehir Agriculture Department, product is taken twice a year in the Eskişehir plains. Firstly, farmers sows forage crops such as silage corn or vetch after sowing agricultural products such as wheat. cultivated land is irrigated with water drawn from rivers and increasingly growing wells in province. Therefore, limiting impact of the climate on agriculture is trying to reduce. Also, plain has got a lower slope to $2 \%$. Soil is deep in the majority of $(77.2 \%)$ the plains, medium depth in the rest of the plains and soil is structures in alluvial. 


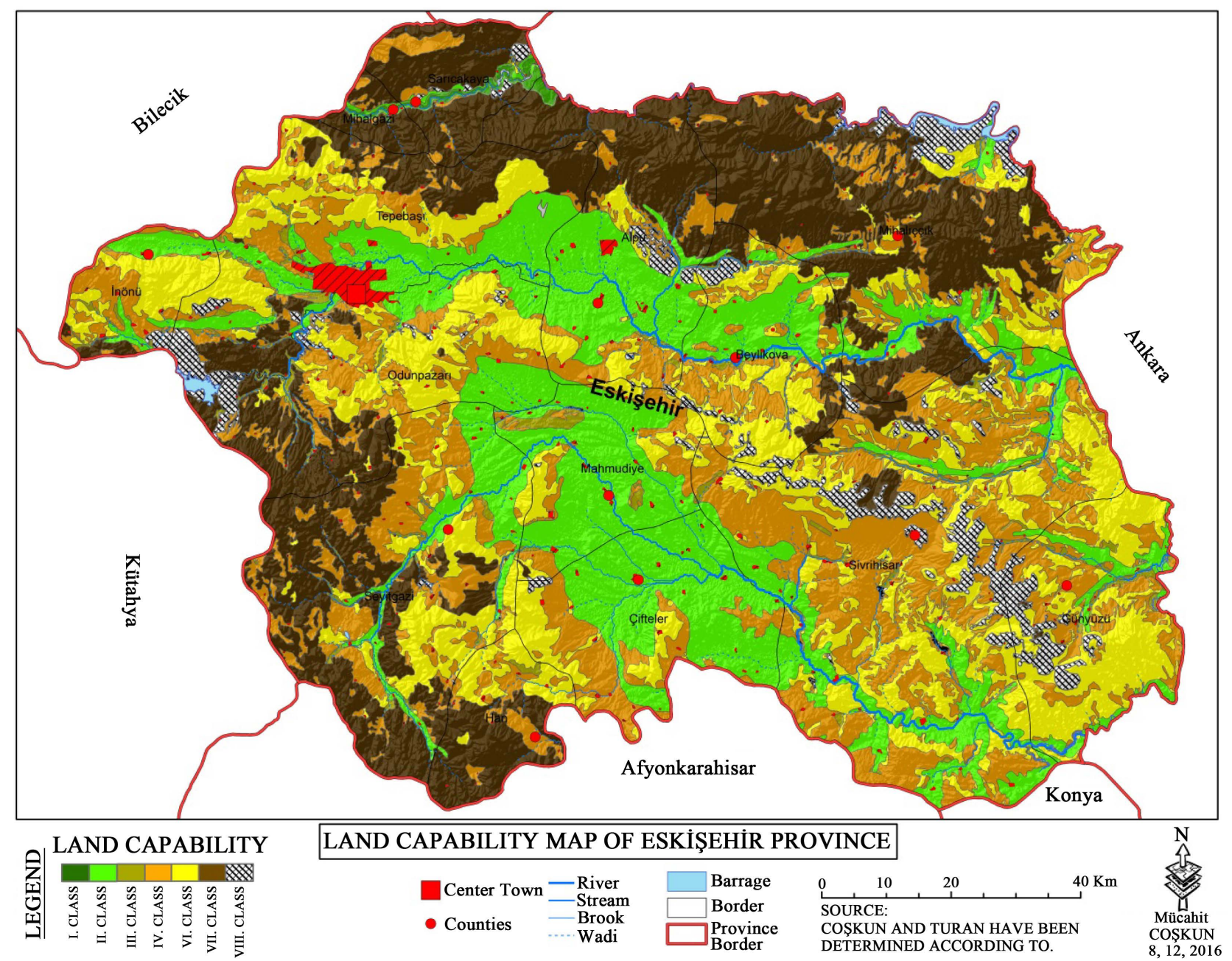

Map 7. Taking into consideration Atalay and Gündüzoğlu's mismatch, The maps of Eskişehir Province landscapes plotted by Coşkun and Turan.

- Atalay and Gündüzoğlu defining class III land as "aqueous agricultural in interior of the areas" and class IV as "dry agriculture in interior of the areas". But part of alluvial soil by the river which is considered to II and IV. Class of land is considered to be class II areas in the re-made map of province. Other land classifications are same as classification map that created by Atalay and Gündüzoğlu.

According to the table, when the land capability of Atalay and Gündüzoğlu are taken into consideration, According to the currently used USA classification system in Eskişehir province;

- There is no I Class, II Class ve V Class land. Because, according to the authors I and II. Territorial land features can only be seen in the areas of the Mediterranean climate region. Because Atalay and Gündüzoğlu claim that in such lands; "Climatic conditions do not have a limiting effect on agriculture" and "the vegetation cycle lasts all year and therefore crops must be harvested at 
least twice in these areas". Because Eskişehir is located in Central Anatolia, it does not have the necessary conditions for I and II. Class lands which. Atalay and Gündüzoğlu referred to. There are also no class $\mathrm{V}$ grounds in the province. Because according to Atalay and Gündüzoğlu class $V$ landmarks have "drainage problems" which are often covered with sand and gravels as a result of floods. According to Eskisehir DSİ data, there are not frequent floods in the province.

- III. Class land 106,920 hectares VII. Class land showed a decrease of 152,000 hectares; whereas Class area is 535,207 hectares and VI. Class land has increased by 75,474 hectares.

- Atalay and Gündüzoğlu, define III. Class land as "land where some fruits and vegetables are grown in the inner regions.” According to Atalay and Gündüzoğlu, in accordance with the classification system of land capability according to the US classification system in the province of Eskişehir. When the III class land conditions are compared, there is a difference of 106,920 hectares. Because the US classification system considers the land, which is mostly dry farming done, as a III class land.

- Atalay and Gündüzoğlu, define IV. Class land as "land where cereals are grown in dry areas in the inner regions". According to the current US classification system and the authors, When the IV. Class land conditions are compared, there is a difference of 535207 hectares. US classification system considers IV. Class land as dry farming and pastureland.

- While Atalay and Gündüzoğuremark VI. Class land as areas suitable for use as grassland in inner areas; according to the US classification system VI. Class areas are partially forested, meadow and pasture areas. Therefore, 75,474 hectares of difference between the two classification systems occurs.

- While Atalay and Gündüzoğlu, define VII. classland as "the places that should be under permanent forest regime"; as US classification system indicates VII. Class land as forests and the lands where the grassland is mostly found, 152 000 hectares of difference occurs.

- According to the US classification system IV, V., VI. and VII. Class agricultural lands are considered to be forest, meadow and pasture land. as well as other agricultural activities, According to Atalay and Gündüzoğlu, VI. Class lands only in the inner regions are considered grassland. Therefore, there are numerical differences between the two classification systems.

- There is no difference in VIII. Class lands. Because such land is a river flood bed and naked rock. Therefore, there is no separate thought on this issue in both classifications.

According to the Table 1, with Atalay and Gündüzoğlu's land capability status, when compared taking into consideration Atalay and Gündüzoğlu's mismatch, the Maps of Eskişehir province landscapes plotted by Coşkun And Turan in Eskişehir province; 
Table 1. Comparative areas covered by landmarks in the maps of Capability organized in Eskişehir.

\begin{tabular}{|c|c|c|c|c|c|c|c|c|c|}
\hline & $\begin{array}{l}\text { I. } \\
\text { Class } \\
\text { Land } \\
\text { (Hectare) }\end{array}$ & $\begin{array}{l}\text { II. } \\
\text { Class } \\
\text { Land } \\
\text { (Hectare) }\end{array}$ & $\begin{array}{l}\text { III. } \\
\text { Class } \\
\text { Land } \\
\text { (Hectare) }\end{array}$ & $\begin{array}{l}\text { IV. } \\
\text { Class } \\
\text { Land } \\
\text { (Hectare) }\end{array}$ & $\begin{array}{l}\text { V. } \\
\text { Class } \\
\text { Land } \\
\text { (Hectar }\end{array}$ & $\begin{array}{l}\text { VI. } \\
\text { Class } \\
\text { Land } \\
\text { (Hectare) }\end{array}$ & $\begin{array}{l}\text { VII. } \\
\text { Class } \\
\text { Land } \\
\text { (Hectare) }\end{array}$ & $\begin{array}{l}\text { VIII. } \\
\text { Class } \\
\text { Land } \\
\text { (Hectare) }\end{array}$ & $\begin{array}{l}\text { TOTAL } \\
\text { (Hectare) }\end{array}$ \\
\hline $\begin{array}{l}\text { The availability of } \\
\text { land capability in } \\
\text { Eskişehir province } \\
\text { (according to USA } \\
\text { classificion system) }\end{array}$ & 124,461 & 198,610 & 149,308 & 142,811 & 3270 & 171,496 & 508,067 & 63,805 & $1,365,248$ \\
\hline $\begin{array}{l}\text { According to Atalay and } \\
\text { Gündüzoğlul and capability } \\
\text { of Eskişehir province }\end{array}$ & - & - & 42,388 & 678,018 & - & 246,970 & 356,067 & 63,805 & $1,365,248$ \\
\hline $\begin{array}{c}\text { Taking Into } \\
\text { Consideration Atalay } \\
\text { and Gündüzoğlu's Mismatch, } \\
\text { The Maps Of Eskişehir } \\
\text { Province Landscapes Plotted } \\
\text { By Coşkun and Turan }\end{array}$ & 3498 & 317,443 & 41,338 & 336,127 & - & 246,970 & 356,067 & 63,805 & $1,365,248$ \\
\hline
\end{tabular}

- There are 3498 hectare I. Class land and 317443 hectare II. Class land. Atalay and Gündüzoğlu think that there is no I. and II. class land in Eskisehir owing to the location of it, in the land capability classification system that they formed.

- However, as a result of field observations made by Coşkun and Turan, there is a Class I land in the alluvial area in the vicinity of the Sakarya River. Because the greenhouse activities carried out at this point of the province, the negative impact of climate on agriculture has been lifted and it can be taken 4 - 5 times a year. In addition, according to Atalay and Gündüzoğlu, because of fulfilling the other conditions of being Class I land, Sarıcakaya and Mihalgazi which are located here is the area of Class I land.

- According to Coşkun and Turan, alluvial lands on the edges of Sakarya, Porsuk and other rivers in the Eskişehir plain; areas on the sides of Saricakaya and Mihalgazi, the areas which are on the sides of Class I lands are class II lands Because all of these alluvial fields are being harvested twice a year, and one of these products is usually industrial plants. In addition, alluvial lands have a slope of $2 \%$ less and $77.2 \%$ of the soil in depth. In other words, this part of the land meets the condition of being an II. class land which is revealed by Atalay and Gündüzoğlu.

- While III. Class land 1050 hectare, IV. Class land 341891 hectare show difference; there is no difference in V, VI, VII and VIII. Class lands. The cause of the difference that emerges in III and IV. The class lands are the following: While Atalay and Gündüzoğlu define III. Class land as "irrigated farming areas in inner regions", IV. Class land is defined as "areas of dry farming in the inner regions". However, in the province, according to Coskun and Turan 
because III and IV. Class lands, in the reconstructed mapping the alluvial soils, which are in the river edges of the areas are considered as class I and II lands, a numerical difference has occurred.

While the world population is increasing rapidly, the requirements are also increasing. One of the most important and most basic of these requirements is food and it is obtained from the soil. In order to protect the soil and to get the highest yield from it, every country uses different technologies. Natural conditions are tried to be overcome with the help of technology. To be able to use the technology usefully comes about by doing the planning right. In today's world, it has become an imperative that realistic land-use planning for countries, the current agricultural policies, to be able to become self-sufficient without being dependent to foreign countries on food. When compared to many countries, Turkey is advantageous due to its position, local features and its competitive capacity is high. The issues such as wrong agricultural policies, incorrect land use issues, false legislation applications made lowers our potential mentioned. In this study, it has been understood that the land capability classification application is inadequate and wrong in many properties. It is essential to redo land capability classification considering Turkey's ecological conditions with regard to regions' and local areas' properties.

\section{References}

[1] Atalay, İ. and Gündüzoğlu, G.A. (2015) Land Capability Classification by Turkey’s Ecological Conditions. Meta Printing Services 87, Sokak No. 4/A Bornova, İzmir.

[2] FAO (1993) Guidelines for Land Use Planning. FAO Development Series 1, FAO, Rome.

[3] Everest, T., Akbulak, C. and Özcan, H. (2011) Evaluation of Land Use Efficiency: Case of Havsa District of Edirne Province. Journal of Anatolian Agricultural Sciences, 216, 251-257.

[4] EserÜnaldı, U., Aksoy, B., Coşkun, M. and Özcan, E. (2007) Effect of Incorrect Use of the Land on Urbanization and Environment (Sample of Bursa Plain). 38th International Congress of Asian and North African Studies, Ankara, 10-15 September 2007, 375-387.

[5] Atalay, İ. and Değerliyurt, M. (2015) Land Capability Classification at the Burdur Basin. Proceedings of the 4th National Geomorphology Symposium, Samsun: Nineteen May University, Bologna, 26-30 October 2015, 500-520.

[6] Babalık, A. (2002) Issues Concerning Use of Land in the Region of Isparta. Süleyman Demirel University Journal of Forestry Faculty, A, 63-81.

[7] Buldan, İ. and Gülersoy, A.E. (2003) Relationship between Land Use and Classifications in Gömeç Basin (Balıkesir). SırrıErinç Geography Symposium's Expanded Abstracts, Framework of 550, Foundation Year Activities of Istanbul University, İstanbul University Press, İstanbul, 249-255.

[8] Gülersoy, A.E. (2013) Bakırçay Havzas'nda Jeolojik Litolojik Özellikler İle Arazi Kullanımı Arasındaki İlişkiler. Ege Üniversitesi Yayınları Edebiyat Fakültesi Yayın No. 180, 539-552.

[9] Gülersoy, A.E. and Çelik, M.A. (2014) Temporal Change of Land Use Small Men- 
deres Basin (1984-2012). Geographers Association International Conference Proceedings, 832-838.

[10] Gülersoy, A.E., Gümüş, N., Sönmez, M.E. and Gündüzoğlu, G. (2015) Relations between the Land Use and Capability Classification in Küçük Menderes River Basin. Journal of Environmental Biology, 36, 17-26.

[11] Anonymous (2001) The Presence of Land Eskişehir Province. The Turkish Prime Ministry, General Directorate of Rural Services Publications Provincial Report No. 26, Ankara.

[12] Gülersoy, A.E. (2014) Incorrect Land Use. Electronic Journal of Social Science Education, 2, 49-28.

[13] Gözler, M.Z., Cevher, F. and Küçükayman, A. (1986) Geology and Water Resources vicinity of Eskisehir. MTA Journal, 103-104, 40-54.

[14] Atalay, İ. and Mortan, K. (1997) Regional Geography of Turkey. İnkılap Bookshop, İstanbul.

[15] http://www.mgm.gov.tr/veridegerlendirme/il-ve-ilceler-istatistik.aspx?m=ESKISEH IR\#sfB

[16] Yiğitbaşoğlu, H. (2000) Accidentally Made in the Use of Agricultural Land in Turkey and Their Major Sample: Eskişehir. Ankara University, Language and HistoryGeography Faculty Journal, 40, 3-12.

[17] Representatives of the Chamber of Agricultural Engineers Eskisehir Province (1995) Evaluation in Terms of Land Use of Land in the Eskisehir Province Central District. Agriculture and Engineering Journal, No. 49, 32-38.

[18] Ministry of Agriculture and Rural Affairs. General Directorate of Agricultural Production and Development 2008 Classification Standards and Technical Instructions of Soil and Land and Relevant Legislations.

[19] Interview with Atalay, İ. (2016).

\section{Submit or recommend next manuscript to SCIRP and we will provide best service for you:}

Accepting pre-submission inquiries through Email, Facebook, LinkedIn, Twitter, etc.

A wide selection of journals (inclusive of 9 subjects, more than 200 journals)

Providing 24-hour high-quality service

User-friendly online submission system

Fair and swift peer-review system

Efficient typesetting and proofreading procedure

Display of the result of downloads and visits, as well as the number of cited articles

Maximum dissemination of your research work

Submit your manuscript at: http://papersubmission.scirp.org/

Or contact gep@scirp.org 